\author{
MARCIN KAMIŃSKI \\ ORCID: 0000-0003-3036-4297 \\ Uniwersytet Warszawski \\ kaminski.marcin@yahoo.com
}

\title{
Kto strzeże konkurencji na rynku energetycznym? Między Prezesem URE a Prezesem UOKiK - wybrane zagadnienia
}

\begin{abstract}
Abstrakt: Artykuł jest omówieniem wybranych zagadnienień dotyczących wzajemnych relacji między Prezesem URE i Prezesem UOKiK w kontekście zapewniania konkurencji w sektorze energetycznym. W pracy przedstawiono zarys rozdzielenia uprawnień obu organów wynikający z orzecznictwa Sądu Najwyższego oraz poglądów doktryny. Na przykładzie zasady dostępu stron trzecich oraz postanowień rozporządzenia REMIT autor starał się dowieść tezy o komplementarności zakresu zadań obu organów oraz niezbędności ich współpracy. Wskazano, że mnogość potencjalnych działań stosowanych przez przedsiębiorstwa energetyczne wymaga współdziałania ze strony organów w ramach podzielonych kompetencji. W celu udowodnienia, że do zbliżonych stanów faktycznych zastosowanie mogą mieć zarówno przepisy regulacji sektorowych, jak i przepisy o ochronie konkurencji, autor przytoczył praktykę decyzyjną Komisji oraz organów w innych państwach członkowskich UE. Podsumowując rozważania podjęte w niniejszym artykule, stwierdzono, że kluczem do realizacji celu polegającego na zapewnieniu skutecznych mechanizmów ochrony konkurencji jest współpraca i chęć wykonywania istniejących kompetencji przez oba organy strzegące konkurencji w sektorze energetycznym.
\end{abstract}

Słowa kluczowe: konkurencja, rynek energetyczny, Prezes Urzędu Regulacji Energetyki, Prezes Urzędu Ochrony Konkurencji i Konsumentów.

\section{Wstęp}

Wprowadzenie i ochrona konkurencji na rynku energetycznym stanowi istotne zadanie legislacyjne, z którym mierzą się zarówno instytucje Unii Europejskiej, jak i ustawodawcy i właściwe instytucje państw członkowskich ${ }^{1}$. Skuteczna

1 Zob. B. Nowak, Wewnętrzny rynek energii w Unii Europejskiej, Warszawa 2009; oraz A. Szafrański, Prawo energetyczne, wartości i instrumenty ich realizacji, Warszawa 2014, s. 89 n.

Prawo 329, 2020

(C) for this edition by CNS 
liberalizacja sektora energetycznego nie jest możliwa bez istnienia organów wyposażonych w odpowiednie kompetencje umożliwiające im czuwanie nad stanem rozwoju rynku.

Na poziomie Unii Europejskiej Komisja Europejska (dalej: Komisja lub KE) jest odpowiedzialna za zapewnienie odpowiedniego funkcjonowania rynku energii - jednego z celów Traktatu o funkcjonowaniu Unii Europejskiej². W Polsce zaś istnieją dwa główne organy strzegące konkurencji w omawianym sektorze. Zadania z zakresu regulacji gospodarki paliwami i energią oraz promowania konkurencji realizuje Prezes Urzędu Regulacji Energetyki ${ }^{3}$ (dalej: Prezes URE). Jednocześnie Prezes Urzędu Ochrony Konkurencji i Konsumentów (dalej: Prezes UOKiK) jest, co do zasady, organem właściwym w sprawach ochrony konkuren$\mathrm{cji}^{4}$. Prezes UOKiK jest organem ochrony konkurencji, natomiast Prezes URE jest organem regulacyjnym, któremu przysługują pewne, określone szczegółowo w ustawach, uprawnienia związane z ochroną konkurencji na rynku energii. W tym zakresie Prezes URE oraz Prezes UOKiK mają wspólny cel — zapewnienie i ochronę konkurencji na rynku.

Jak wskazano w doktrynie, odrębność ustrojowa organu ochrony konkurencji i organów regulacyjnych implikuje konieczność wyraźnego określenia ich kompetencji tak, aby stosowane przez nie instrumenty prawne wzajemnie się uzupełniały, tworząc spójny system prokonkurencyjnych środków oddziaływania na rynek ${ }^{5}$. W praktyce pojawiło się jednakże wiele wątpliwości i sporów dotyczących wzajemnych relacji kompetencyjnych pomiędzy Prezesem URE a Prezesem $\mathrm{UOKiK}^{6}$. Co więcej, w polskim porządku prawnym brakuje klarownego rozdziału kompetencji obu omawianych organów oraz reguł kolizyjnych związanych z równoległym stosowaniem ustawy Prawo energetyczne i ustawy o ochronie konkurencji ${ }^{7}$. W rezultacie odpowiedź na, istotne z prawnoustrojowego oraz praktycznego punktu widzenia, pytanie o wzajemną relację zakresu zastosowania obu ustaw oraz kompetencje właściwych organów podjęto w orzecznictwie i doktrynie.

Celem niniejszego artykułu nie jest kompleksowe opisanie relacji kompetencji Prezesa URE i Prezesa UOKiK. Autor, przyjmując znaczny dorobek doktryny w tym zakresie, stawia sobie za zadanie zbadanie dotychczasowych ustaleń w omawianym zakresie w świetle dwóch szczególnych sytuacji — odmowy

2 Art. 194 Traktatu o funkcjonowaniu Unii Europejskiej (Dz.U. z 2004 r. poz. 90.864/2).

3 Art. 21 ustawy z dnia 10 kwietnia 1997 roku Prawo energetyczne (Dz.U. z 2019 r. poz. 755); dalej: ustawa Prawo energetyczne.

4 Art. 29 ust. 1 ustawy z dnia 16 lutego 2007 roku o ochronie konkurencji i konsumentów (Dz.U. z 2019 r. poz. 369); dalej: ustawa o ochronie konkurencji.

5 Por. C. Banasiński, Równoległe stosowanie instrumentów prawa konkurencji i instrumentów regulacyjnych $w$ Polsce (na przykładzie telekomunikacji i energetyki), [w:] Prawo konkurencji - stan obecny oraz przewidywane kierunki zmian, red. C. Banasiński, Warszawa 2006, s. 99.

6 Ibidem, s. 94.

7 M. Szydło, Prawo konkurencji a regulacja sektorowa, Warszawa 2010, s. 217-229. 
dostępu do sieci oraz kontroli przeprowadzonej na podstawie rozporządzenia nr 1227/2011 z dnia 25 października 2011 roku w sprawie integralności i przejrzystości hurtowego rynku energii ${ }^{8}$ (dalej: rozporządzenie REMIT). Jednocześnie autor stoi na stanowisku, że kompetencje obu organów w polskim porządku prawnym nie zostały rozgraniczone w sposób ostateczny, a działania rynkowe, których mogą dopuścić się przedsiębiorcy, sprawiają, że postawione w temacie artykułu pytanie pozostaje aktualne. W artykule wyrażono także przekonanie, że konkurencji w sektorze energetycznym strzegą oba organy, a o skuteczności ich działań decyduje ich współpraca w obliczu wyzwań.

\section{Ogólne rozwiązania dotyczące wzajemnych relacji Prezesa UOKiK i Prezesa URE}

Jak wskazano we wstępie, zgodnie z ustawą Prawo energetyczne Prezes URE wykonuje zadania z zakresu spraw regulacji gospodarki paliwami i energią oraz promowania konkurencji. Jednocześnie należy zauważyć, że rozwój konkurencji na rynku energetycznym stanowi jeden z celów omawianej regulacji. Prezes URE bierze pod uwagę także takie wartości, jak bezpieczeństwo energetyczne czy ochrona środowiska. W ramach wykonywania zadań związanych z konkurencją w sektorze energetycznym Prezes URE ma szczegółowe kompetencje, takie jak (omówione w dalszej części pracy) uprawnienia związane z odmową dostępu stron trzecich do infrastruktury.

Prezes UOKiK jest organem odpowiedzialnym ogólnie za ochronę konkurencji. Możliwość wykonywania przyznanych mu w ustawie o ochronie konkurencji uprawnień nie jest jednak nieograniczona. Zgodnie z art. 3 ustawy o ochronie konkurencji przepisów tej ustawy nie stosuje się do ograniczeń konkurencji dopuszczonych na podstawie odrębnych ustaw. Ogólne postanowienia przedmiotowej ustawy zawierające zakazy zawierania niedozwolonych porozumień czy też nadużywania pozycji dominującej nie mają zatem zastosowania, gdy szczegółowe przepisy innej ustawy dopuszczają dane działanie podmiotów. Jak podkreślono w doktrynie, jeżeli zachowanie przedsiębiorcy wypełnia wszystkie przesłanki niezbędne do zakwalifikowania go jako praktyki ograniczającej konkurencję, lecz istnieje przepis innego aktu prawnego, który je autoryzuje w określonych przypadkach, to takie zachowanie tego przedsiębiorcy nie może być sankcjonowane na gruncie ustawy o ochronie konkurencji ${ }^{9}$. W efekcie należy wskazać, że podsta-

8 Rozporządzenie Parlamentu Europejskiego i Rady (UE) nr 1227/2011 z dnia 25 października 2011 roku w sprawie integralności i przejrzystości hurtowego rynku energii, Dz.Urz. L 326, 8.12.2011, s. 1-16.

9 Ustawa o ochronie konkurencji i konsumentów. Komentarz, red. A. Stawicki, E. Stawicki, LEX 2019. 
wową zasadą rozdziału kompetencji między Prezesem URE a Prezesem UOKiK jest lex specialis derogat legi generali. Została ona rozwinięta zarówno w doktrynie, jak i orzecznictwie Sądu Najwyższego.

Omawiając wzajemne relacje regulacji sektorowych oraz ustawy o ochronie konkurencji, Sąd Najwyższy zauważył, że w takim zakresie, w jakim przedmiotem regulacji sektorowej jest problematyka prawna ochrony konkurencji, a więc regulacja sektorowa, która ma na celu wspieranie równoprawnej i skutecznej konkurencji w zakresie świadczenia usług $\mathrm{w}$ danym sektorze, przepisy regulacji sektorowej mają charakter regulacji ustawowej szczególnej (lex specialis) względem ogólnych zasad prawnych dotyczących problematyki ochrony konkurencji, które zostały określone przepisami ustawy o ochronie konkurencji (lex generalis) ${ }^{10}$. Samo istnienie regulacji sektorowej dotyczącej konkurencji na danym rynku nie wyłącza jednak kompetencji Prezesa UOKiK. Aby dany przepis stanowił lex specialis we wskazanym rozumieniu, należy spełnić jeszcze jeden warunek. Aprobując konkluzje wynikające z unijnego prawa ochrony konkurencji, Sąd Najwyższy potwierdził, że przepisy prawa ochrony konkurencji znajdują zastosowanie do działalności przedsiębiorstw objętych regulacją we wszystkich tych przypadkach, $\mathrm{w}$ których przepisy regulacyjne pozostawiają im margines swobody działania ${ }^{11}$. Dodatkowo, aby przepisy regulacji sektorowej wyłączały możliwość zastosowania ustawy o ochronie konkurencji, muszą także regulować dane zagadnienie w sposób kompleksowy ${ }^{12}$. Jeśli zaś dane rozwiązania zawarte w ustawie Prawo energetyczne pomijają pewne stany faktyczne, wówczas przepisy ustawy o ochronie konkurencji mogą potencjalnie znaleźć zastosowanie.

Ważnym aspektem wzajemnych relacji między Prezesem UOKiK a Prezesem URE jest również posiadanie kompetencji do rozstrzygnięcia sprawy. W doktrynie przyjmuje się, że podjęcie działań reglamentacyjnych przez Prezesa URE wyłącza możliwość następczych działań Prezesa UOKiK ${ }^{13}$. Są także głosy stwierdzające, że samo uprawnienie Prezesa URE do władczego rozstrzygnięcia danej sprawy wyłącza możliwość podjęcia działania przez Prezesa UOKiK ${ }^{14}$. Teza taka może jednak budzić wątpliwości. Wydaje się, że z punktu widzenia ochrony konkurencji na rynku pożądane jest, aby w wypadku niepodjęcia działań ze strony Prezesa URE organ odpowiedzialny za ochronę konkurencji mógł interweniować, jeśli zachowanie danego przedsiębiorstwa spełniałoby przesłanki zastosowania na

10 Uchwała Sądu Najwyższego z dnia 7 grudnia 2005 roku, sygn. III SZP 3/05, OSNP 2006, nr 7-8, poz. 124.

11 Wyrok Sądu Najwyższego z dnia 19 października 2006 roku, sygn. III SK 15/06, ONSP 2007, nr 21-22, poz. 337.

12 Wyrok Sądu Najwyższego z dnia 15 lipca 2009 roku, sygn. III SK 34/08, LEX nr 551867.

13 R. Stankiewicz, Między ochrona konkurencji a regulacja sektorowa. Ustrojowe granice rozdzielenia obszarów ingerencji w gospodarce, „Ekonomia i Prawo” 8, 2012, nr 1, s. 165.

14 J. Baehr, A. Stawicki, Prawo energetyczne jako lex specialis $w$ stosunku do przepisów ustawy o ochronie konkurencji i konsumentów, [w:] Prawo konkurencji..., s. 138. 
przykład art. 9 ustawy o ochronie konkurencji. Na marginesie należy zauważyć, że istnieje więcej zasad wzajemnych relacji obu omawianych organów ${ }^{15}$, jednakże z uwagi na ograniczony zakres niniejszego artykułu nie wszystkie zostaną omówione.

\section{Zasada dostępu stron trzecich — konkurencja czy komplementarność kompetencji?}

Zapewnienie dostępu stronom trzecim do właściwej infrastruktury jest jednym z głównych celów regulacji w sektorze energetycznym ${ }^{16}$. Niektórzy uważają nawet, że stanowi ono podstawowy cel regulacji działalności przedsiębiorców prowadzących działalność w tej gałęzi gospodarki ${ }^{17}$. Zarówno akty prawa Unii Europejskiej, jak i ustawa Prawo energetyczne zawierają szczegółowe zasady udzielania dostępu nie tylko do sieci elektroenergetycznych ${ }^{18}$ i gazowych, ale $\mathrm{i}$ instalacji magazynowych czy też instalacji $\mathrm{LNG}^{19}$. Co istotne, zasada dostępu stron trzecich $w$ sektorze energetycznym nie jest połączona $z$ siłą rynkowych podmiotów zarządzających daną infrastrukturą. $\mathrm{O}$ ile, co do zasady, operatorzy systemów przesyłowych i dystrybucyjnych zajmują na określonym rynku pozycję dominującą, a właściwie monopolistyczną, o tyle przykładowo operatorzy instalacji LNG nie muszą cieszyć się takim statusem. Co więcej, przepisy ustawy Prawo energetyczne nakładają obowiązek udzielania dostępu stronom trzecim bez względu na to, czy dostęp do danej infrastruktury jest niezbędny do prowadzenia danej działalności, czy też istnieją alternatywne możliwości działalności na rynku. Tymczasem obowiązek udzielenia dostępu stronom trzecim na podstawie art. 9 ustawy o ochronie konkurencji i konsumentów lub art. 102 TFUE ciąży jedynie na przedsiębiorstwach mających pozycję dominującą. Związany jest także

15 Zob. M. Szydło, op. cit.

16 Ibidem, s. 72.

17 C. Banasiński, op. cit., s. 108.

18 Zob. art. 32 dyrektywy Parlamentu Europejskiego i Rady 2009/72/WE z dnia 13 lipca 2009 roku dotyczącej wspólnych zasad rynku wewnętrznego energii elektrycznej i uchylającej dyrektywę 2003/54/WE (Dz.Urz. L 211, 14.08.2009, s. 55-93), a także rozporządzenie Parlamentu Europejskiego i Rady (WE) nr 714/2009 z dnia 13 lipca 2009 roku w sprawie warunków dostępu do sieci w odniesieniu do transgranicznej wymiany energii elektrycznej i uchylające rozporządzenie (WE) nr 1228/2003 (Dz.Urz. L 211, 14.08.2009, s. 15-35).

19 Zob. art. 32-33 dyrektywy Parlamentu Europejskiego i Rady 2009/73/WE z dnia 13 lipca 2009 roku dotyczącej wspólnych zasad rynku wewnętrznego gazu ziemnego i uchylającej dyrektywę 2003/55/WE (Dz.Urz. L 211, 14.08.2009, s. 94-136), a także art. 14-19 rozporządzenia Parlamentu Europejskiego i Rady (WE) nr 715/2009 z dnia 13 lipca 2009 roku w sprawie warunków dostępu do sieci przesyłowych gazu ziemnego i uchylającego rozporządzenie (WE) nr 1775/2005 (Dz.Urz. L 211, 14.08.2009, s. 36-54). 
z licznymi innymi warunkami, takimi jak eliminowanie efektywnej konkurencji z rynku przez odmową kontraktowania ${ }^{20}$.

W rezultacie zasada dostępu stron trzecich wyrażona w regulacjach sektorowych ma dużo szerszy zakres zastosowania i prowadzi do przyznania prawa do dostępu do infrastruktury znacznie większej grupie adresatów. Jako że to Prezes URE jest organem właściwym do stosowania regulacji sektorowej, to na tym organie, co do zasady, ciąży obowiązek kontrolowania, czy zasada dostępu stron trzecich do infrastruktury nie podlega naruszeniom dokonywanym przez różnych uczestników rynku. W tym kontekście kompetencje Prezesa UOKiK zostały ograniczone do węższej grupy adresatów — przedsiębiorstw zajmujących pozycję dominującą.

Mechanizm działania zasady dostępu stron trzecich najpełniej odzwierciedla art. 4 ustawy Prawo energetyczne, zgodnie z którym przedsiębiorstwo energetyczne zajmujące się przesyłaniem lub dystrybucją paliw gazowych lub energii jest zobowiązane zapewnić wszystkim odbiorcom oraz przedsiębiorstwom zajmującym się sprzedażą paliw gazowych lub energii, na zasadzie równoprawnego traktowania, świadczenie usług przesyłania lub dystrybucji paliw gazowych lub energii. Świadczenie tych usług jest ograniczone do zakresu uregulowań ustawy Prawo energetyczne. Tak długo jak operatorzy wywiązują się z nałożonego na nich obowiązku, nie powstaje problem związany z ochroną konkurencji. Pojawia się on w sytuacji, gdy operatorzy odmawiają lub utrudniają dostęp do infrastruktury.

Ustawa Prawo energetyczne wprowadza wyjątki od omawianej zasady, pozwalające na odmowę dostępu stronom trzecim. Przedsiębiorstwa energetyczne mogą tak uczynić, powołując się na przykład na zagrożenie niezawodności dostaw (art. 4f ust. 1 ustawy Prawo energetyczne) lub - w wypadku przedsiębiorstw zintegrowanych pionowo - gdy udzielenie dostępu stronom trzecim powodowałoby trudności finansowe lub ekonomiczne związane z realizacją zobowiązań wynikających z uprzednio zawartych umów (art. 4h ust. 1 ustawy Prawo energetyczne). W przypadku odmowy dostępu do infrastruktury przedsiębiorstwa są zobowiązane poinformować o tym Prezesa URE. Organ ten może, po zbadaniu określonych przesłanek, zwolnić czasowo lub ograniczyć stosowanie omawianej zasady do danego przedsiębiorstwa. Za niepoinformowanie Prezesa URE o odmowie świadczenia przedmiotowych usług przedsiębiorstwom grozi kara finansowa; może ona zostać nałożona przez Prezesa URE również za niewywiązywanie się z zasady dostępu stron trzecich.

Należy jednak się zastanowić, czy wskazane regulacje w całości regulują zagadnienie odmowy dostępu do infrastruktury. Jak wskazał bowiem Sąd Najwyższy, w wypadku nieistnienia kompleksowej regulacji zagadnienia dostępu do sieci przesyłowej w Prawie energetycznym nie stanowi ono lex specialis wobec ustawy

20 M. Szydło, op. cit., s. 216 n. 
o ochronie konkurencji ${ }^{21}$. Niektórzy uważają, że przy zawartych w ustawie Prawo energetyczne obowiązkach nie ma możliwości dochodzenia w postępowaniu przed Prezesem UOKiK stwierdzenia naruszenia ustawy o ochronie konkurencji w sytuacji, w której dany podmiot odmawia dostępu stronom trzecim zgodnie z przesłankami zawartymi w ustawie Prawo energetyczne ${ }^{22}$. Zgodzić się należy, że w wypadku indywidualnej odmowy dostępu do infrastruktury to Prezes URE jest organem właściwym do podejmowania działań ${ }^{23}$. Odmowa dostępu do infrastruktury może jednak polegać także na wielu innych działaniach, takich jak nadmiernie wydłużanie czasu trwania negocjacji lub proponowanie warunków umownych, które byłby nie do przyjęcia dla wnioskującego 24 .

W dodatku, interpretując uchwałę Sądu Najwyższego ${ }^{25}$, wydaje się, że możliwe jest, aby Prezes UOKiK prowadził postępowanie dotyczące odmowy dostępu do sieci nie tyle w indywidualnym wypadku, ile zespołu działań związanych z taką odmową, które mogą stanowić nadużywanie pozycji dominującej. Jak podano w doktrynie, taką odmową może być przykładowo sytuacja, w której przedsiębiorstwo energetyczne działa na zasadach dyskryminacyjnych — jednym podmiotom działającym na danym rynku odmawia się dostępu z powołaniem się na przepisy regulacji sektorowej, a innym udostępnia swoją infrastrukturę. Co istotne, Prezes UOKiK mógłby także zająć się strategią antykonkurencyjną dotyczącą zamykania dostępu do rynku innym podmiotom ${ }^{26}$. Komisja, w ramach działań prowadzonych na podstawie art. 102 TFUE, prowadziła już takie postępowania. Jedno z nich zakończyło się nałożeniem kary finansowej w wysokości 77 milionów euro na bułgarskie przedsiębiorstwo za wdrażanie strategii zamykającej dostęp do bułgarskiego gazu, której elementem było blokowanie dostępu do sieci przesyłowej oraz zdolności magazynowych ${ }^{27}$.

Przytoczony przykład postępowania prowadzonego przez Komisję oraz wskazane zapatrywania części doktryny prowadzą do konkluzji, że w obecnym stanie prawnym Prezes UOKiK może także prowadzić postępowanie dotyczące odmowy dostępu stron trzecich do infrastruktury, zwłaszcza gdyby stanowiła ona wyrafinowaną strategię danego przedsiębiorstwa. Prezes URE pozostaje, co do zasady, odpowiedzialny za ochronę konkurencji w zakresie indywidualnych odmów dostępu. Tak długo, jak prowadzi on postępowanie związane ze zgłoszeniem

21 Wyrok Sądu Najwyższego z dnia 15 lipca 2009 roku, sygn. III SK 34/08, LEX nr 551867.

22 C. Banasiński, op. cit., s. 108.

23 Tak Prawo energetyczne, t. 2. Komentarz do art. 12-72, red. Z. Muras, M. Swora, LEX 2019; odmiennie: Ustawa o ochronie...

24 C. Banasiński, op. cit., s. 108.

${ }^{25}$ Uchwała Sądu Najwyższego z dnia 7 grudnia 2005 roku, sygn. III SZP 3/05, OSNP 2006, nr 7-8, poz. 124.

26 Ustawa o ochronie...

27 Komunikat prasowy Komisji, https://europa.eu/rapid/press-release_IP-18-6846_en.htm (dostęp: 30.09.2019). 
odmowy lub utrzymana jest w mocy decyzja zwalniająca przedsiębiorstwo ze stosowania omawianej zasady, kompetencje Prezesa UOKiK są wyłączone. Możliwe zastosowanie przez przedsiębiorców bardziej skomplikowanych działań, innych niż dokonanie wprost odmowy dostępu, sprawiają jednakże, że zarówno Prezes URE, jak i w odpowiednim zakresie Prezes UOKiK strzegą stosowania tej kluczowej dla sektora energetycznego zasady. Pożądaną sytuacją jest, aby w kontrolowaniu wykonywania omawianej zasady oba organy współpracowały z sobą w jak najszerszym zakresie.

\section{Rozporządzenie REMIT — możliwość współpracy}

Rozporządzenie REMIT zawiera przepisy dotyczące niedozwolonych praktyk wpływających na hurtowe rynki energii. Ma ono zastosowanie do wszystkich rynków państw członkowskich Unii Europejskiej, na których prowadzony jest obrót produktami energetycznymi sprzedawanymi w obrocie hurtowym. Produktami objętymi reżimem prawnym rozporządzenia REMIT są umowy i instrumenty pochodne od umów na dostawy energii elektrycznej lub gazu ziemnego, a także kontrakty i instrumenty pochodne związane z umowami na przesył energii elektrycznej lub gazu ziemnego.

Rozporządzenie REMIT jest szczególnie istotne $\mathrm{z}$ uwagi na to, że coraz bardziej powszechny na rynkach energii staje się obrót giełdowy. W polskim porządku prawnym ustawodawca wprowadził obowiązek sprzedaży zarówno energii elektrycznej, jak i gazu ziemnego na giełdzie towarowej lub rynku regulowanym. Obowiązek ten ukształtowany jest odmiennie dla energii elektrycznej i gazu. Nie wchodząc w szczegóły postanowień art. 49a i 49b ustawy Prawo energetyczne, warto zauważyć, że w wypadku rynku polskiego rozporządzenie REMIT odgrywa niebagatelne znaczenie.

Omawiany akt prawny wprowadza dwa główne zakazy związane z obrotem na hurtowym rynku energii. Po pierwsze, ustanawia zakaz wykorzystywania informacji wewnętrznych. Za takie informacje należy uznać niepodane publicznie informacje, które mogą znacząco wpływać na ceny produktów energetycznych. Po drugie, rozporządzenie REMIT wprowadza zakaz dokonywania lub usiłowania manipulacji na hurtowych rynkach energii. Manipulacja lub jej próba rozumiana jest przy tym szeroko. Mogą za nią zostać uznane wszelkie próby generowania fałszywych lub wprowadzających w błąd sygnałów cenowych czy też działania mające na celu ustalenie cen na sztucznym poziomie. Co istotne, rozporządzenie REMIT nie przewiduje konkretnych kar za naruszenie nakładanych przez ten akt prawny obowiązków. Obowiązek zapewnienia stosowania zakazów ciąży na organach regulacyjnych. 
Organ regulacyjny w Hiszpanii miał już okazję zastosować omówione postanowienia. W dniu 24 listopada 2015 roku hiszpańska Komisja Rynków i Konkurencji (hiszp. Comisión Nacional de los Mercados y la Competencia, dalej: CNMC) nałożyła na spółkę Iberdrola Generación karę pieniężną w wysokości 25 milionów euro za manipulacje na hurtowym rynku energii elektrycznej. CNMC uznała, że w okresie od 30 listopada do 23 grudnia 2013 roku Iberdrola Generación stosowała strategię polegającą na podnoszeniu cen energii produkowanej w elektrowniach wodnych na rzekach Duero, Sil i Tajo. Spółka pomimo wzrostu cen energii na rynkach nie oferowała części mocy zarządzanych elektrowni wodnych, które miesiąc wcześniej były jeszcze dostępne i oferowane. Zdaniem CNMC strategia miała na celu umożliwienie wejścia na rynek droższych elektrowni turbinowych gazowo-parowych, które zostały uruchomione przy odpowiednio wysokim poziomie cen.

Warto przy tym zauważyć, że CNMC jest organem odgrywającym rolę zarówno ochrony konkurencji, jak i sprawującym nadzór nad sektorem energetycznym. W tym wypadku ustawodawca hiszpański nie musiał więc zastanawiać się nad modelem współpracy organów w przypadku wykonywania rozporządzenia REMIT. Co istotne, kara została nałożona na podstawie zakazów wynikających z REMIT. Iberdrola Generación dysponowała w owym czasie blisko $40 \%$ zdolności wytwórczych w Hiszpanii. Istniała zatem możliwość, aby została na nią nałożona kara na podstawie przepisów związanych z nadużywaniem pozycji dominującej.

Przypadek prowadzenia postępowania związanego z manipulacją cenami na hurtowym rynku energii na podstawie przepisów o ochronie konkurencji miał też miejsce przed wprowadzeniem rozporządzenia REMIT. Komisja badała wówczas działalność spółki E.ON ${ }^{28}$. Uznano, że niemieckie przedsiębiorstwo, które kolektywnie zajmowało pozycję dominującą na rynku sprzedaży hurtowej energii, stosowało strategię polegającą na niedopuszczaniu na rynek tańszych mocy wytwórczych w celu wykorzystywania droższych jednostek i osiągnięcia wyższych cen $^{29}$. Komisja nie nałożyła na spółkę kary, lecz przyjęła decyzję zobowiązującą przedsiębiorstwo do zbycia $5000 \mathrm{MW}$ mocy wytwórczych ${ }^{30}$. Z omówionej sprawy wynika, że kwestie manipulacji na hurtowym rynku energii mogą znaleźć się również $\mathrm{W}$ zakresie zastosowania prawa ochrony konkurencji. W danym stanie

28 Sprawa COMP/39.388, Niemiecki rynek hurtowy energii elektrycznej, https://europa.eu/ rapid/press-release_IP-08-1774_en.htm?locale=en (dostęp: 28.09.2019).

29 M.D. Diathesopoulos, From energy Sector Inquiry to Recent Antitrust Decisions in European Energy Markets: Competition Law as a Means to Implement Sector Regulation, s. 17, https:// papers.ssrn.com/sol3/papers.cfm?abstract_id=1639883 (dostęp: 30.09.2019).

${ }^{30}$ M. Sadowska, Energy liberalization in Antitrust Straitjacket: A plant too far?, „World Competition: Law and Economics Review" 34, 2011, nr 3, s. 16, https://papers.ssrn.com/sol3/papers.cfm?abstract_id=1806530 (dostęp: 30.09.2019). 
faktycznym kara może zatem zostać nałożona przez organ do spraw ochrony konkurencji.

W polskim porządku prawnym zdecydowano się na wprowadzenie rozwiązania instytucjonalnego opartego na współpracy trzech organów w ramach egzekwowania rozporządzenia REMIT - Prezesa URE, Prezesa UOKiK oraz Przewodniczącego Komisji Nadzoru Finansowego (dalej: Przewodniczący KNF). Zasada współpracy w omawianym zakresie została wyrażano w art. $23 \mathrm{~m}$ ustawy Prawo energetyczne, a także art. 31 ustawy o ochronie konkurencji. Warto jednak zauważyć, że postanowienie dotyczące współpracy z innymi organami w ramach wykonywania obowiązków z zakresu rozporządzenia REMIT jest jedynym dotyczącym tego aktu prawnego, które znajduje się w podstawowym dla Prezesa UOKiK akcie. Natomiast ustawa Prawo energetyczne zawiera wiele przepisów tyczących się REMIT. Wynika z niej, że to Prezes URE przeprowadza kontrolę lub prowadzi postępowanie wyjaśniające $\mathrm{w}$ sprawach manipulacji na rynku lub próby manipulacji na rynku oraz niezgodnego z prawem wykorzystywania informacji wewnętrznej w zakresie produktów energetycznych sprzedawanych w obrocie hurtowym, które nie są instrumentami finansowymi. Można pokusić się zatem o tezę, która ma odzwierciedlenie w praktyce, że to Prezes URE wiedzie prym w nadzorowaniu rynku w zakresie REMIT. Warto w tym miejscu dodać, że w 2018 roku Prezes URE wszczął dwa postępowania dotyczące możliwych manipulacji na hurtowym rynku energii elektrycznej ${ }^{31}$.

Współpraca pomiędzy wspomnianymi organami jest niezbędna z punktu widzenia wymierzania kar. O ile Prezes URE ma wystarczające uprawniania, aby samemu przeprowadzić skuteczną kontrolę REMIT, o tyle jego możliwości kontrolne są ograniczone podmiotowo. Przepisy karne zawarte w art. 57a-57e ustawy Prawo energetyczne odnoszą się jedynie do osób fizycznych. Aby za działania niezgodne z rozporządzeniem REMIT zostało ukarane przedsiębiorstwo, tak jak w omawianych wcześniej sprawach, postępowaniem muszą się zająć albo Prezes UOKiK, albo Przewodniczący KNF ${ }^{32}$. Prezes URE nie ma jednak wystarczających narzędzi legislacyjnych, aby przeprowadzić postępowanie w zakresie rozporządzenia REMIT w pełni, nakładając karę na przedsiębiorstwo oraz osoby fizyczne. Jednocześnie warto zauważyć, że nawet przeprowadzenie omawianego postępowania i wymierzenie kary na osoby fizyczne przez Prezesa URE nie wyłącza możliwości działania Prezesa UOKiK w tym zakresie. Dzieje się tak z uwagi na charakter kar nakładanych przez omawiane organy. Prowadzi to do konkluzji, że w zakresie rozporządzenia REMIT, z punktu widzenia skuteczności i pełności postępowań, pożądana jest współpraca między Prezesem URE, Prezesem UOKiK, a także Przewodniczącym KNF.

31 https://www.ure.gov.pl/pl/urzad/informacje-ogolne/aktualnosci/7956,Kolejne-postepowanie-Prezesa-URE-dotyczace-badania-ewentualnych-manipulacji-na-r.html (dostęp: 29.09.2019).

32 Ustawa z dnia 26 lipca 2016 roku o nadzorze nad rynkiem finansowym (Dz.U. z 2019 r. poz. 298). 


\section{Podsumowanie}

Ochrona konkurencji w sektorze energetycznym jest jednym z podstawowych wyzwań związanych z tą gałęzią gospodarki. W tym kontekście kluczową rolę odgrywają organy, którym zostało powierzone zadanie kontrolowania i promowania konkurencji na omawianym rynku. Prezes URE pełni główne funkcje w zakresie wdrażania przepisów zawartych w ustawie Prawo energetyczne. Zarówno w zakresie zapewnienia funkcjonowania kluczowych zasad liberalizacji rynku energii, jak i w ramach przepisów mających na celu zapobieganie manipulacjom na rynkach hurtowych niezbędne jest jednak wprowadzenie reguł gwarantujących skuteczne egzekwowanie uchwalanych zasad. Jednocześnie ustanowienie w regulacji sektorowej wielu zasad, takich jak zasada dostępu stron trzecich do infrastruktury czy też zasad zatwierdzania taryf, nie sprawia, że Prezes UOKiK jest zwolniony $\mathrm{z}$ czuwania nad stanem konkurencji na tym rynku.

Bez względu na ustalone reguły kompetencyjne, zapatrywania doktryny czy wyroki Sądu Najwyższego dotyczące rozdziału zadań między Prezesa URE a Prezesa UOKiK, najważniejszym celem jest, aby — w ostatecznym rozrachunku — zapewnić skuteczność wprowadzanych zasad i efektywnie odstraszyć przedsiębiorstwa od stosowania niedozwolonych praktyk. W tym aspekcie, nawet w obliczu niedostatecznych regulacji ustawowych, istotna jest faktyczna współpraca pomiędzy omawianymi organami. Współdziałanie i wzajemna komunikacja między nimi stanowi bowiem niezbędny warunek właściwego funkcjonowania systemu rozdzielonych kompetencji w zakresie ochrony konkurencji na rynkach regulowanych.

\section{Bibliografia}

Diathesopoulos M.D., From Energy Sector Inquiry to Recent Antitrust Decisions in European Energy Markets: Competition Law as a Means to Implement Sector Regulation, https://papers. ssrn.com/sol3/papers.cfm?abstract_id=1639883.

Nowak B., Wewnętrzny rynek energii w Unii Europejskiej, Warszawa 2009.

Prawo energetyczne, red. Z. Muras, M. Swora, t. 2. Komentarz do art. 12-72, LEX 2019.

Prawo konkurencji - stan obecny oraz przewidywane kierunki zmian, red. C. Banasiński, Warszawa 2006.

Sadowska M., Energy liberalization in Antitrust Straitjacket: A plant too far?, „World Competition: Law and Economics Review" 34, 2011, nr 3.

Stankiewicz R., Między ochrona konkurencji a regulacja sektorowa. Ustrojowe granice rozdzielenia obszarów ingerencji w gospodarce, „Ekonomia i Prawo” 8, 2012, nr 1.

Szafrański A., Prawo energetyczne, wartości i instrumenty ich realizacji, Warszawa 2014.

Ustawa o ochronie konkurencji i konsumentów. Komentarz, red. A. Stawicki, E. Stawicki, LEX 2019. 


\title{
Who safeguards the competition in the energy market? Between the President of the Energy Regulatory Office and President of the Office of Competition and Consumer Protection - selected issues
}

\begin{abstract}
Summary
The aim of this paper is to discuss the selected issues concerning the mutual relations between the President of the Energy Regulatory Office and President of the Office of Competition and Consumer Protection. The outline of the distinction of powers of both authorities resulting from the case of law of the Supreme Court and views expressed in the doctrine is presented. Based on the examples of third-party access rule and the provisions stipulated in the REMIT regulation, the author intended to prove the claim that the assignments of both authorities are complementary and the cooperation between them is indispensable. It is also indicated that the variety of practices which could be implemented by the energy enterprises requires the collaboration between the authorities within the framework of the shared competences. In order to demonstrate that the provisions of sector specific regulations and provisions of competition law might both be applicable to very similar factual situations, the author presented the decisions taken by the European Commission and national authorities in other member states. Concluding the deliberations expressed in this paper it is claimed that the key issue for fulfilling the objective consisting of providing the effective mechanism of competition protection is the cooperation and willingness to perform existing competences by both authorities safeguarding competition in the energy sector.
\end{abstract}

Keywords: competition, energy market, President of Energy Regulatory Office, President of the Office of Competition and Consumer Protection. 